\title{
BIRD AS A SUBJECT IN WOOD CARVING MOTIFS: AN OBSERVATION ON BAJAU TRADITIONAL WEAPONS
}

\author{
Mohammed Iqbal Badaruddin,,$^{1 *}$ Simon Soon, ${ }^{2}$ Luqman Lee, ${ }^{3}$ Zaimie Sahibil ${ }^{4} \&$ \\ Mohd Shahrul Hisham Ahmad Tarmizi ${ }^{5}$ \\ "First author \\ 1,2,3Jabatan Seni Visual, Pusat Kebudayaan, Institut Pengajian Siswazah, \\ Universiti Malaya, Kuala Lumpur \\ ${ }^{4} J a b a t a n$ Seni Visual, Fakulti Kemanusian, Seni dan Warisan, \\ Universiti Malaysia Sabah, Kota Kinabalu, Sabah \\ 5 Jabatan Seni Halus, Universiti Teknologi MARA Cawangan Kelantan \\ Kelantan, Malaysia \\ (iqbal688@uitm.edu.my; simonsoon@um.edu.my; luqlee@um.edu.my; \\ affymie@ums.edu.my; mshahrulhisham@gmail.com) \\ DOI: https://doi.org/10.22452/brj.vol13no1.7
}

\begin{abstract}
The wood carving on the hilt and sheath (taguban) of parang (machete) created by the Bajau craftsmanship in Kota Belud is well-known for its uniqueness across Sabah. This study discusses the stylisation and value of appreciation from the philosophy of Bajau's craftsmanship and the influence of the wood carving motif designs. The subject of birds is interpreted as a pattern in wood carving on either on the hilt, the tagubantaguban (sheath) or bladed weapon. Among the examples of bird's subjects include hornbills, birds, manuk (rooster) and naga (dragons). This study aims to comprehend Bajau's parang weapons, addressing the bird's motif and its connection to mythical and cosmological values and why the study of the values expressed Bajau craftsmanship concerning the principles of Malay aesthetics as it expands the cultural reach of the Bajaus across the Malay Archipelago. This research is conducted through in-depth interviews with Bajau parang craftsmen as well as through participant observation at their workshop and exhibitions. Semantic Differential method is used in the research to understand what the larger community of Bajau craftsmen recognise to be the values inherent in their artform. The authors refer to Zakaria Ali's six principles of Malay aesthetics to understand how the parang-wood carving traditions of the Bajau conform to these principles. It is within this early cosmopolitan history that the bird design motif can be understood as a motif that embodies both local
\end{abstract}


interpretive frames yet also resonant within a broadly comparative cosmology of Islam in the Malay World.

Keywords: bird, wood carving, design, motif, traditional weapons, mythology, cosmology, philosophy, culture, Bajau Darat.

\section{Introduction}

The uniqueness of Bajau Sama carvings in Sabah is one of the attractions for both local as well as international wood carving enthusiasts. In addition to the wood carving of the hilt and taguban of Bajau traditional weaponries, other forms of wood carvings produced by the ethnic include the lepa-lepa (traditional boat), traditional houses, furniture and home appliances, graveyards and tombstones.

In general, the carving motifs are among the heritage of art that have been inherited from the time before the coming of Islam to Sabah in 13th century CE. It is often regarded as the identity and symbol of culture and customs for every tribe in Borneo. As it illustrates the cultural values and beliefs of mythology and cosmology of the local community, there are often significant differences in every motif produced by the tribes in Sabah. The design and pattern of each motif interact between one ethnic to another. This can be seen through the pattern on Bajau carving motifs which are influenced by the China and Tausug community in the Southern Philippines. Ismail Ibrahim, Mohd Azareen Aminullah, Humin Jusilin, Mohd Pu'ad Bebit, and Zaimie Sahibil (2013) states that the Bajau carving motifs have changed due to Islamisation, assimilation, and acculturation in Sabah and this unique design will develop from time to time. Hence, the scope of this study is to examine the uniqueness of the carved motifs on the hilts and taguban of Bajau traditional weapons that were inspired by birds, manuk (rooster) and naga (dragon).

\section{Literature Review}

Previous studies on the Bajau Laut community have focused on their spiritual values and customs. This includes the Sama language and its dialects (Miller et al., 2007), the Bajau Laut community in Semporna (Ismail Ali, 2010), their culture and identity (King, 2013, p.25), the Bajau's traditions from the perspective of the Islamic law (Syamsul Azizul Marinsah, Mohammad Naqib Hamdan, Mohd. Farhan Md. Ariffin, \& Mohd. Anuar Ramli, 2016), and the influence of traditional and Islamic culture on the community's death and ritual evolution (Halina Sendera Mohd. Yakin, 2013). Most researchers argue that the influence of Islamic art philosophy was not practised in the design of the Bajau Darat wood 
carving motifs as most of the parang makers were more inclined to the commercial value of Bajau machetes and knives (Ismail Ibrahim et al., 2013; Noorajamsha Nasrin, \& Azizan H. Morshidi, 2015). Nevertheless, the Bajau Darat craftsmen are still visualising the design of wood carving motifs under the influence of Islamic art and culture, particularly those who refer to environmental elements such as plants, animals, marine life, cosmic, and spiritual elements (Ismail Ibrahim, Mohd Azareen Aminllah, Humin Jusilin, Mohd Pu'ad Bebit, Zaimie Sahibil, 2013). These elements can often be found in the carving motifs of traditional houses, weapons and armours, houseboats or lepa, home furniture, and daily tools.

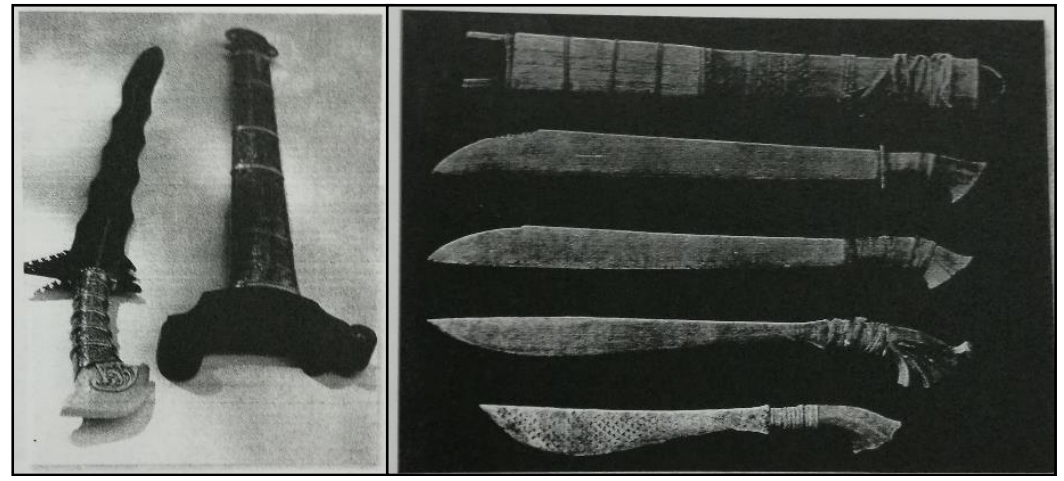

Figure 1: An Illustration of Bajau Traditional Weapon, Circa 1690s (Source: Cojuangco [2005, pp. 87, 114].)

Several influential factors are affecting the design of patterns found in the traditional weapons of Bajau Darat such as hereditary, their backgrounds, cultural values, mythological influence and cosmological value. Nevertheless, these factors are influenced by the process of civilisation through inter-port trades from China and western countries as well as the increase in the surrounding economies such as the marine products, the supply of traditional weapons and other equipment due to the raiding activities around 12 century (Warren, 2003; Ismail Ali, 2010).

While the findings by Ismail Ibrahim (2009), and Baszley Bee Basrah Bee, Md. Saffie A Rahim, Muhd. Shaukhi M. Radzi, and Ismail Ali (2015) illustrate the effect of Islamisation and that the struggle in the establishment of Islam among Bajau, Iranun, Samal, Tausug and local ethnics has proven the impact of strong belief, especially in the early 1900s. This is due to the influence of mythology from Hinduism, the Philippines, and the cosmological values from the Bajau ancestors are still strong (Cuthbert, 1960). Hence, it changes their culture and practices as Muslims in Sabah. 
The depiction of bird as a representation of motif design in any art form have been commonly practised among skilled Bajau Sama craftsmen in Philippines primitive art, especially Sulu archipelago. However, after the Islamisation during pre-Spanish time, the stylisation of motif design in Bajau wood carvings are denaturalised with plant form and usually appeared in their torogan, lepa and sunduk (graveyard). It is believed that the depiction of bird motif in their traditional wood carvings can bring hope, fortune and protection from embo'-embo' (evil spirit) (Baradas, 1968; Peralta, 1980; Nimmo, 1990).

\section{Research Methodology}

The research design of this study involves qualitative methods of in-depth interviews, direct observations, and secondary data collections. Among the informants interviewed were Tuan Hj. Ebin B. Adim, Hj. Ab. Majad Halim, and Jamawid B. Soh who are three Bajau Darat craftsmen involved in the parang making industry in Kota Belud, Sabah. The interview also involved appointments and discussions with several academicians to consult on the suitability of this article. Meanwhile, secondary data collection was based on scientific books, academic dissertations and theses, as well as published journal articles. Whereas, anthropological approaches to art and semantic differential theory refer to the methods in analysing the process of engraving the motifs. Such method assists in understanding the meaning and cultural values of birds as a subject in creating wood carving motifs.

\section{Problem Statement}

The lack of studies about bird-pattern design motifs in Bajau Darat's traditional weapon has created an illustration about the cultural value of Bajau community. Previous studies have focused on the Bajau parang design by comparing the unique Bajau traditional weapons with the Bajau craftsmanship as well as the cultural values of wood carving motifs (Noorajamsha Nasrin, \& Azizan H. Morshidi, 2015). In addition, several studies have also focused on traditional medicine, marriages, traditional dances and performances, and rituals that are practiced in the Bajau community (Halina Sendera Mohd. Yakin, 2013; Saidatul Nornis, 2016; Syamsul Azizul Marinsah \& Mohd. Anuar Ramli, 2017).

The mystical perception of traditional Bajau weaponry is always associated with the animism elements in their practices and activities which are inherited from previous generations as well as other ethnic groups in Southern Philippines include Borneo such as the Kadazan-Dusun community or the Iban 
community in Sarawak. The mystical perception of the Bajau community manifests a sense of prejudice especially by the people outside the community after embracing Islam on the 13th century (Lailawati Madlan, Chua Bee Seok, Jasmin Adela Mutang, Shamsul Amri Baharudin, \& Ho Cheah Joo, 2014). Therefore, it is important to understand the beliefs, abstinence practices, as well as the development process and change of motif design after the Islamisation, particularly among the Bajau Darat community in Kota Belud, Sabah.

\section{Bajau Traditional Weapon in Kota Belud}

Aligned with the concept of Pelancongan Berasaskan Komuniti (PBK) or Community-Based Tourism inculcated among rural communities in Sabah, craftsmen in the Kota Belud district have been actively producing Bajau parang. Statistics by the Ministry of Tourism, Culture, and Environment Sabah (KEPKAS), the number of tourists who visited Sabah has increased to 3 million between 2002 to 2014 (Mohd. Jirey Kumalah et al., 2015). In this regard, Tun Dr Mahathir Mohammad has emphasised on the importance of constructing a new strategy that ensures the development of hand-made arts among craftsmen especially the rural areas (Noorajamsha Nasrin, \& Azizan H. Morshidi, 2015). They also found that the implementation of the Dasar Industri Kreatif Negara (DIKN) on indigenous handicrafts among craftsmen in Sabah and Sarawak has succeeded in increasing their productivity due to the demand from local and international markets.

The positive impact of this tourism sector has led to an increase in demand from traditional weapon collectors. Bajau parang makers are now provided with the option to market their products through online sales with the help of the latest technology. According to Noorajamsha Nasrin and Azizan H. Morshidi (2015), there are approximately 50 to 80 Bajau parang makers in Kota Belud. This includes areas such as Kampung Siasai Jaya, Kampung Siasai Kumpang, Kampung Siasai Dundau, Kampung Siasai Tamu, Kampung Rampayan Ulu and Kampung Rampayan Laut. However, according to master craft Tuan Jamawid Soh, the number of parang makers has increased by the end of 2018, and it is estimated that there are nearly 80 Bajau parang makers in Kampung Siasai Jaya solely.

Bajau traditional weapons are commonly known as parang (machete). However, the community classifies parang into several types according to its function. This includes pidah, kagayan, karis (kris), guk lading, badih or baladau, parang sundai or sundang, beliung lun, budjak and seruit (spear), and barong (Ismail Ibrahim, 2009, p. 2). 


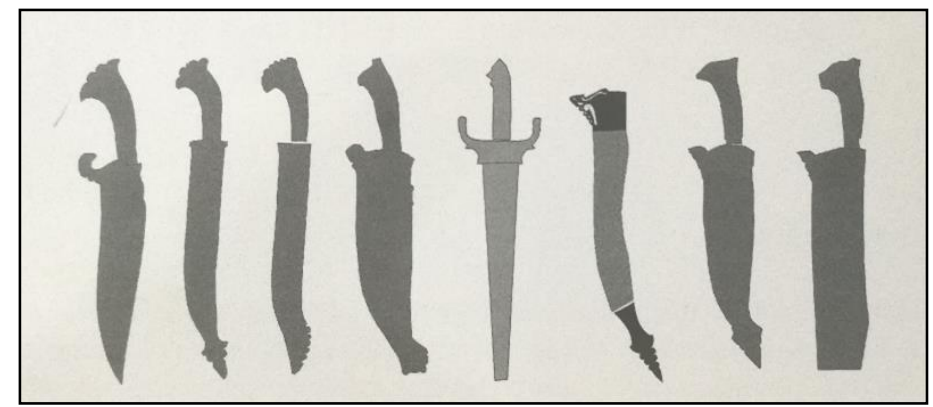

Figure 2: Types of Bajau Traditional Weapon in Kota Belud (Source: Ismail Ibrahim [2009, p.106].)

\section{The Philosophy of Bajau wood carving}

Carving, or ukkil in the Hiling-Sama language spoken by the Bajau, Tausug, Samal, and Jama Mapun, refers to the expertise of sculpting on a surface such as a piece of paper, house walls, tables, traditional clothing, body tattoos, or handicraft products. According to Amilbangsa (2006), ukkil or okil (in Tagalog; ukit) is a term that refers to decorating design on a particular surface and is often referred to as the art of sculpting. However, the term ukkil may also be construed as painting, knitting, weaving, decorating, or mould casting. While according to Baradas (1968), the Sulu ethnics used the term as okil or okil-okil in producing their arts.

The philosophy of Bajau wood carving in Kota Belud generally contains similarities with the philosophy in the art of Bajau parang making. This is because most parang makers or panday basey also possess the knowledge and skills in wood carving, especially in producing parang, the hilts or taguban and other Bajau traditional weaponries. Furthermore, the art of wood carving is also bounded with several traditional beliefs. For instance, the panday kahuy believe that the wood carving process can only be done in the morning. The engraving tools should also be continuously sharpened and cannot be used by other woodcarvers as it might injure the owner and others as well as causing damage to the engraved motifs. According to Hj. Majad Halim, the pattern of engraved motifs should be guided by Islamic teachings. For example, it is common for motifs that resemble spiritual elements such as gimbaran (neutral spirit) mantra/spells, or other religious symbols to be carved onto the Bajau parang blade. It is believed that evil elements can exist in traditional weapons and they will be questioned by the embo'-embo in the hereafter (Halina Sendera Mohd. Yakin, 2013). 


\section{The Influence of the Bajau wood carving Motif Design}

Generally, the pattern and design of every motif produced by the ethnics in Borneo affect each other. However, the most significant influence in the Bajau Sama pattern is from the Iranuns and Tausug ethics of the Southern Philippines especially in Sulu and Mindanao. This has resulted from the trades between the aristocrats and merchants from China and India as well as human trafficking by the sea pirates. According to Warren (2003), the Sultan and the elites from Sulu, Balangingi, Guangzhou (Canton), and London used to have global relationships among each other particularly in the 18th and early 19th century.

Trafficking activities involving ethnic groups in Sulu archipelago such as Iranun, Tausug, Visaya, Tagalog, Malay, and Moro slaves from outside the Balangingi Sama community had illegally allowed them to learn the language, culture, and beliefs. Warren (2003) states that the majority of these slaves were skilled in art crafting and craftsmanship. As a result, the influence of their skills and expertise is visible in the Samal/Sama and the Bajaus of the Balangingi. Furthermore, Amilbangsa (2006) suggests that traders from China began to have diplomatic relations with the Sulu government during the reign of the Yuan Dynasty. This happened between 1278 to $1368 \mathrm{CE}$ when tea powder, ceramic vases, clothing, and wooden products were used as exchange tools between the Emperor of China and the Sultan of Sulu. Cojuangco (2005) in his book The Samals: In History and Legend states that the Samal/Sama (Bajau) communities in the Balangingi Island managed to save themselves from the brutal massacre committed by the Spanish soldiers around 1848 to 1858 CE. Ismail Ibrahim et al. (2013) explains that the Bajau community experienced the process of acculturation and assimilation as the community of the Sea Gypsies in Sabah due to the tradeoff between elites in the glory days of Sulu Sultanate based in Jolo. According to Ismail Ibrahim et al. (2013):

The Maguindanao sultanate around 1203/1205CE was an Islamic Malay empire which ruled parts of Mindanao in the Southern Philippines and expanded its influence from the Zamboanga Peninsula to Sarangani Bay. But for nearly 300 years, the Spanish government succeeded in colonizing the Philippines from the 16th century until the early 19th century.

Based on a preliminary note, Mohd. Shaukhi, Bazley Bee, and Ismail Ali (2015) argue that there are several residents of the Southern Philippines of Sulu archipelago consisting of Bajau, Tausug, Iranun, and Maranao ethnics who have migrated to North Borneo (Sabah) due to the political impact of the Sultan of Sulu 
and the effects of British colonisation in the 17th century. Baszley Bee Basrah Bee, Md. Saffie A Rahim, Muhd. Shaukhi M. Radzi, and Ismail Ali (2015) further adds that such condition resulted in the existence of diplomatic relations and cooperation between Bajau and Iranun around the 1840s especially during their political and economic domination along the west coast of Borneo to Teluk Marudu.

The impact of this administration has led to the influence and stylisation of the pattern and motifs design from previous generations through the value of local cultures and their philosophy, beliefs, and cosmology that was practised centuries ago. These influences include the Hindu, Chinese and Philippine mythology such as Garuda (eagle), Indra (rain and storm god), Sarinaga, Sarimanuk, Makara (animal goddess of God Ganga), Gandaberunda (double-headed bird), Surmalongsong (God of the Seas) or Tikbalang (Demetrio, 1974; Miller et al., 2007). Such influence is based on the Hindu religion that has spread across the Philippines at the end of the 12th century. Billman Cuthbert (1960) states that although the Bajau and other ethnics of Southern Philippines embraced Islam from the Arab missionaries during the pre-Spanish time, there is still common practise of beliefs from the local custom compared to the Islamic tradition. According to Vic Hurley (1936),

With the passing of the Hindu influence, the Philippines experienced a century of contact with the Javanese. From about 1330, the brilliantwinged Praos of the invading Javanese empire of Madjapahit touched the shores of Sulu for a period of seventy years, to sail off eventually on the northeast monsoon and return no more. (p. 15)

An example of influence from the Philippine mythology is the Manananggal creature in the Tagalog, Bikol and Waray mythology. In the Bajau mythology, Manananggal refers to Balan-Balan or Penanggal. This mythology is considered as practical among several individuals in the Bajau Ubian communities within the archipelago of the East Coast of Sabah such as Pulau Banggi, Libaran Island, Jambongan, and Mantanani Island. Hence, the Bajau Ubian community had studied some of the spells and used parang as a 'shield' against the evil creatures.

Nevertheless, the design of the Bajau pattern and motifs have slowly changed and developed due to the impact of Islamisation in the 14th century which prioritises the elements of flora, fauna, cosmos, or subjects that are not contrary to Islam (Amilbangsa, 2006; Ismail Ibrahim et al., 2013). However, based on several observations and interviews with Bajau craftsmen, the authors argue 
that a trace of elements from the Philippine myths still exists although it has been indirectly neutralised by Arab-Persian myths and legends such as Rakhsh, Shabrang, Ruk, Huma, and Azhdaha. In addition, there are also several elements of wood carving motifs that were influenced by other forms of art produced by the Bajau Laut and Bajau Suluk communities in east-coast of Sabah such as lepa and sunduk.

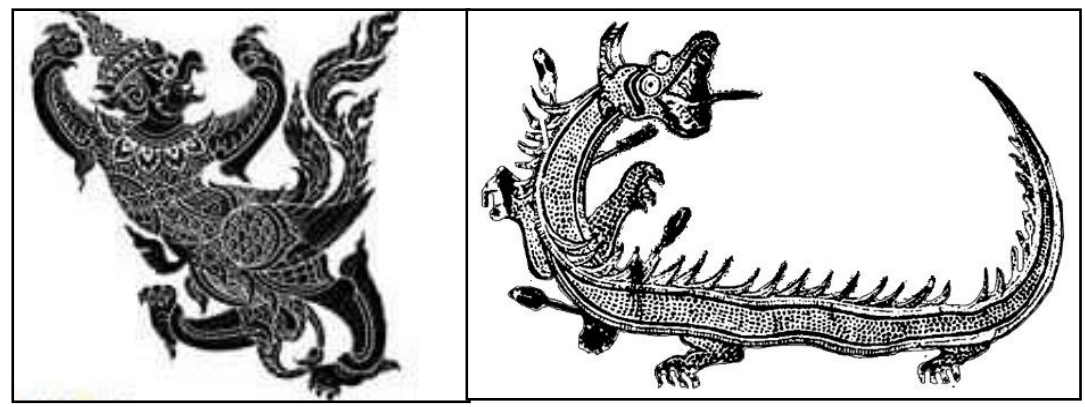

Figure 3: Artist Illustrates an Image of Garuda and Azhdaha in Hindu and Arabic Mythology

\section{Fauna Elements in Traditional Bajau Weapons}

The fauna element refers to the value of carving patterns of animal-shaped motifs. The design of such a motif is inspired by the observation of the surrounding animals based on their respective characters and habits. However, in the philosophy of Bajau wood carving, the selection of animal as a subject should be culturally appropriate and needs to adhere to the Islamic aesthetic value. Among the fauna elements found in Bajau wood carvings include horse leg, manuk , belek/beleh (eagle), burung Raja Udang (kingfisher) or known as the Burung Pimping in the Hiling-Sama, prawns, fish, tiger, and deer. However, this research focuses on the subject of the bird as a reference in producing the design of the motif of the hilt and taguban of Bajau traditional weapon in Kota Belud, Sabah.

\section{Birds}

Bird is a subject that is synonymous with the motifs of traditional wood carving in the archipelago. It is usually characterised as an animal with a pair of wings, a beak, and the ability to fly. The subject of birds comprises several species such as rooster or birds. It also exists in various forms and perceptions of every mythology and cosmology of all religions, races, and ethnicity throughout the world.

Bird subject is often associated with religious and cultural symbols of a place such as the story of the Ababil as mentioned in surah Al-Fil (105: 1-5). In fact, in the Arab-Persian mythology, the subject of Huma Bird, also known as Homa, is 
drawn as a legendary bird that is believed to provide luxury and good fortune. In addition, some bird species are also found in the Arab-Persian mythology such as Simurgh, Ruk and Chamrosh (Khani, Ghasemi, \& Razmjooee, 2007; Seyed Reza Ebrahimi \& Elnaz Valaei Bakhshayesh, 2013) The bird species in the Arab-Persian mythology is believed to have influenced some craftsmen through Islamic civilisation and culture in the Malay Archipelago. According to Jalil Borham (2014:2), the process of Islamisation that took place at the end of the 12th century was due to the impact of the entrepôt relation between Arab traders and the Malay empires through India and Indochina. As stated by Amilbangsa (2006):

...the Sari-Manuk is believed to be of Chinese origin. It is described as a bird of prey holding a fish in its claws / beak, a bird of messenger or some poetic character in different form from folklore to folklore of the Muslims in Southern Philippines. (p. 24)

Meanwhile, Peralta (1980) states that the Chinese paintings, design and colour are quite common and difficult to separate among the ethnics in the Philippines especially the geometric form.

Garuda is a species of bird found in Indonesian mythology through the belief of myths and Hindu-Buddhist legends. However, Waterson (1989) argues that garuda is an animal that God Vishnu rode in the air.

Manuk-Buwangsi is also found in the Sulu-Filipino myths and legends. It is also known as Katakata and is often portrayed as the character of a strong and mighty bird. In his argument, Amilbangsa (2006) states that a bird known as Sarimanuk is always illustrated in the batik art in the Malays, Siamese, and Indian culture. In Chinese culture, birds are called Feng or Feng-Huang, which refers to a Phoenix that has beautiful and coloured wool-like peacocks. Ali Rahman (2005) states that the subject of Burung Cenderawasih or Paradisaea Raggiana is always reflected in the beliefs and cultures of the peninsular Malay community with the ability to protect his master from harassments and grant sustenance. He also noted that in the British colonial period in Malaya, Burung Cenderawasih was built as a ride for the Kelantanese royalty. Meanwhile, according to M. Tajulhadis (2011, p.24), the hornbill or enggang is considered as a symbol of courage and fame in the beliefs of the Iban community in Sarawak. The subject is often illustrated on their parang hilt such as parang Langgai Tinggang which means the longest tail of the hornbill.

The discussion above suggests that the bird subject is particularly popular in the Bajau culture because they are considered as a symbol of peace, beauty, agility, and intelligence. Said Pawel (36) states that the bird subject is usually 
illustrated on Bajau traditional weapons as the Motobelek motif (eagle's eye), Kekubelek motif (eagle's talons or claws), and Pimping motif (kingfisher). Whereas, the parang hilts are usually carved in the form of Tindukbelek (eagle's beak).

\section{Manuk}

Rooster, referred to as manuk in the Hiling-Sama language, is another bird species that is included in the mythology and cosmology of most religion, race, and ethnicity. In the cosmological value of the Chinese belief, rooster (jie 鸡) is one of the zodiacs in their calendar. According to Chinese legends, chickens are able to protect themselves from the disruption of evil spirits. This is believed to provide sustenance onto one's social life for being diligent and seeking to achieve success.

According to informants, the subject of manuk contains fauna elements used in the design of traditional carving patterns on Bajau weapons and it was inherited from the previous craftsmen. Although manuk cannot fly and live on the ground, it is still regarded as part of the bird species as it possesses similar characteristics with birds. Among the ukkil motif designs of manuk are Lawi Manuk, Lembayu'/Lembayung Manuk (rooster's spurs), Perek/Pere'Manuk (rooster's crest), Tikuk Manuk (rooster's head) and Ringayad (rooster's neck). According to Hj. Majad Halim (59), manuk is an interesting subject as the craftsmen of Bajau Kota Belud are from the Bajau Darat group. This animal is more prominent among the Bajau Darat community as it is not only regarded as tame but also as a source of staple food.

Furthermore, the manuk subject is often referred as the symbol of art and agility. This is due to the nature of manuk that often crow early in the morning which is aligned with the Bajau culture and routine of waking up early to perform subuh (dawn) prayer and start working early in the morning. Whereas, in the case of martial arts, a rooster is considered as an agile animal due to its ability to compete and fight with larger and venomous animals like snakes.

$\mathrm{Hj}$. Majad Halim explained that the previous generation of Bajau enjoyed leisure activities and one of the activities was cockfight (bersabung). Observation on the activity had inspired the craftsman to portray the animals on the hilt of their traditional weapons. Such practice is believed to give confidence to the parang owner during combat and self-defence as the manuk shaped tilt blesses the parang with the nature of manuk that jumps and stabs its opponents using its taji. Taji, or spur, is a type of self-defence mechanism that is a pointed, rigid, and grow on the inner leg of a rooster. 


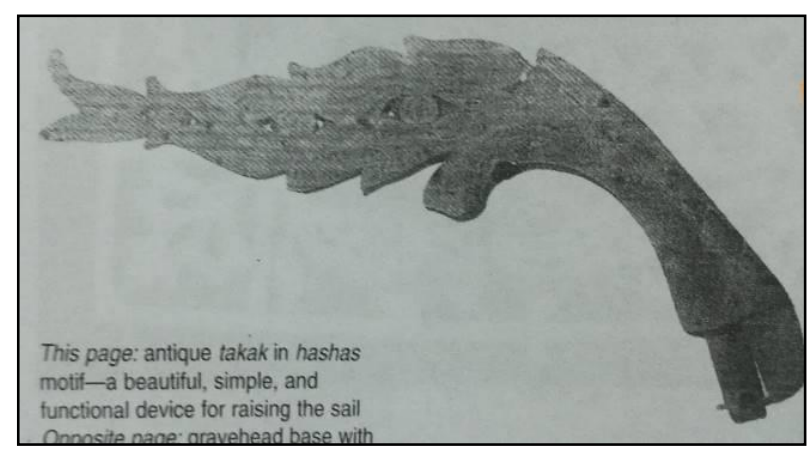

Figure 4: Subject of Naga that is Carved on a Takak (a Device that is Used to Raise the Sail)

(Source: Amilbangsa [2006, p. 22].)

Naga

Naga or dragon is an animal that is formed by the combination of several animals such as eagles, lions, pythons, fish, and crocodiles. This subject is often used as an inspiration by every nation in the Malay Archipelago in the context of religion, culture, myths, and legends of previous generations. Naga symbolises a legendary heroic animal that has magical powers and is believed to be able to bring fortune according to the cultural values of certain communities in the archipelago.

Waterson (1989) states that dragon, in the beliefs of the Maloh, Kayan, and Kenyah communities in Borneo, is a mythical underwater animal as well as a symbol of ngaju. Farish A. Noor and Khoo (2003) in their book Spirit of Wood: The Art of Malay Woodcarving highlight on the existence of the naga, garuda, gunungan, stupa, and makara motifs engraved by Malay woodcarvers during the pre-Islamic times in the 12th century (Nursuriani Shafee \& Ismail Said, 2013). Meanwhile, Amee Joan reports that naga carvings were also found on the taguban of parang Ilang and parang Nyabor from the Ibans of Sarawak.

In the Bajau community, naga is considered as a legendary animal that symbolises fertility and can only be found in the sky or in the sea. According to Amilbangsa (2006), the inhabitants of the small archipelago in Southern Sulu used certain terms to describe dragon such as Sarinaga, Nayaga, or Nagayoda. Peralta (1980) mentioned that the earliest and the most common use of animate abstractions are naga and the sarimanok especially in Maranaw art. While Baradas (1968) explained that it is a common practice using naga figure among the Badjao where it is also known as duyang-duyang, kora-kora or the possibility of its being a seahorse. In the practice of the Bajau community in Sabah, naga is also referred in Bajau tekodon (puzzle game in the form of rhymes or poetry) as the art of performances and entertainment during the celebration of certain events such as 
weddings or celebrating new-born babies (Asmiaty Amat \& Lokman A. Samad, 2013).

However, Said Pawel states that the craftsmen of the younger generation widely practiced most naga-crafted motifs on Bajau parang. This is due to the fact that craftsmen tend to incline towards flora elements design while obeying their previous masters. However, the new generation of Bajau parang makers are not barred as such. Hence, they are likely to appreciate innovation and improvements to the design of the previous pattern as long as the ukkil motif is produced in accordance to the Islamic syariah and adhere to the customs of the Bajau Darat community. Said also believes that there is nothing wrong with illustrating the naga motif as it is just a legendary animal and a myth rather than an animal that is banned in Islam such as wild boars or dogs.

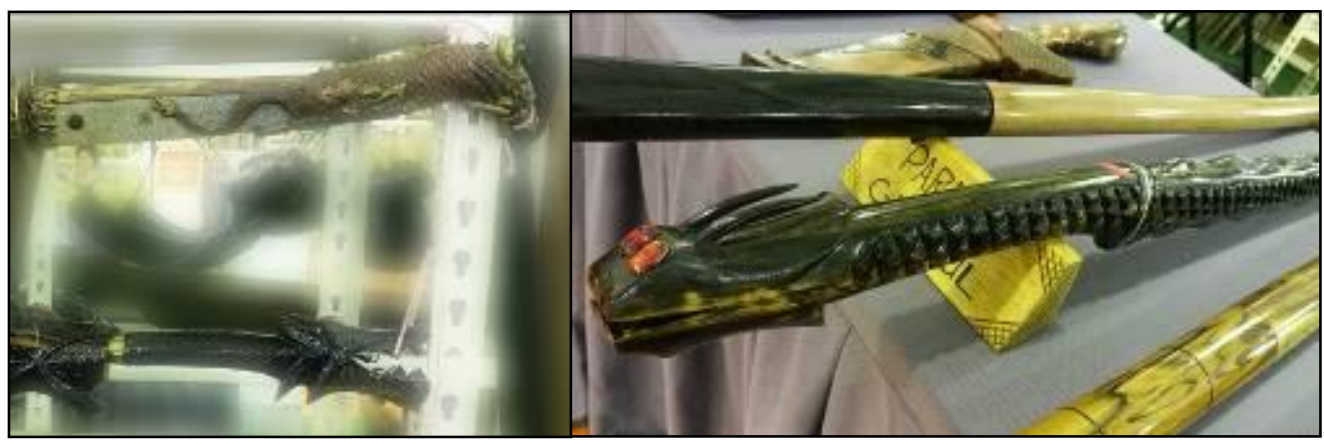

Figure 5: Weapons that Incorporated the Naga Motif were Displayed During the National Kraf Day (HKK) 2019, Kompleks Kraf, Kuala Lumpur.

(Source: Fieldwork, 2019).

\section{Analysis of Birds, Manuk, and Naga Motifs on Bajau Traditional Weapons}

The author refers to the motifs of birds, manuk, and naga found on several weapons produced by the Bajau parang makers. Upon obtaining comments and views from Tuan Arin B. Usop (79) who is one of Bajau parang masters (adiguru), the author made several sections in the form of columns before interviewing another 5 Bajau parang makers who have been involved in Bajau parang industry for more than 5 years. The purpose of this interview is to determine whether the result of the pattern design motifs is agreed by other Bajau parang makers using the semantic differential method. The analysis comprises the interpretation of meanings, symbols, identities, and values in wood carving according to the suitability of motif pattern designs such as composition and engraving techniques. The interviews conducted with the Bajau parang makers were assessed on a scale of 1 (disagree) to 5 (strongly agree). Comments and opinions were also obtained 
from these informants to support the findings further. This method can be assessed in a structured and orderly manner as well as looking at the similarities and differences in the aspects of value appreciation and meaning the principle of art and crafts in Malay aesthetic specially.

\section{Table 1: Analysis of Bird Motif Design}

\begin{tabular}{|c|c|c|c|c|}
\hline Motif & $\begin{array}{l}\text { Pictures and illustrations of the } \\
\text { motif design }\end{array}$ & $\begin{array}{l}\text { Design form } \\
\text { and } \\
\text { composition of } \\
\text { motif }\end{array}$ & $\begin{array}{c}\text { Principle } \\
\text { of Art and } \\
\text { crafts in } \\
\text { Malay } \\
\text { aesthetic }\end{array}$ & Philosophy \\
\hline $\begin{array}{l}\begin{array}{l}\text { Tindukbelek } \\
\text { (eagle's head) }\end{array} \\
\text { Motobelek } \\
\text { (eagle's eye), } \\
\text { circa 1940s }\end{array}$ & & $\begin{array}{l}\text { Parang hilt } \\
\text { (organic shape; } \\
\text { Primary motif) } \\
\text { Parang Barung, } \\
\text { Karis, Kagayan, } \\
\text { Lading \& Pidah }\end{array}$ & $\begin{array}{l}\text { Principle } \\
\text { of: Berhalus } \\
\text { (indirect), } \\
\text { Bersatu } \\
\text { (unity), } \\
\text { Berguna } \\
\text { (functional } \\
\text { ), Bermakna } \\
\text { (meaning) } \\
\& \\
\text { Berlambang } \\
\text { (symbols) }\end{array}$ & $\begin{array}{l}\text { The resemblance of the } \\
\text { head and eye of an eagle } \\
\text { is illustrated on the edge } \\
\text { of the parang. The } \\
\text { suitable size makes it } \\
\text { easy for the edge to be } \\
\text { grasped and they are } \\
\text { able to support the } \\
\text { length of the blade } \\
\text { between } 12 \text { to } 14 \text { inches } \\
\text { long. While the parang is } \\
\text { referred to the nature of } \\
\text { iron which must be } \\
\text { sharp and not blunt. It is } \\
\text { a parable to the Bajau- } \\
\text { minded that must be } \\
\text { sharpened, wise and far- } \\
\text { fetched as well as to } \\
\text { improve other skills and } \\
\text { abilities such as martial } \\
\text { arts, craftsmanship, } \\
\text { farming, agriculture etc. }\end{array}$ \\
\hline $\begin{array}{l}\text { Kekubelek } \\
\text { (eagle's } \\
\text { talons), circa } \\
\text { 1940s }\end{array}$ & & $\begin{array}{l}\text { Pidah's blade } \\
\text { and taguban } \\
\text { Pidah (organic } \\
\text { shape) } \\
\text { Pidah Hilt } \\
\text { (organic; } \\
\text { secondary motif) } \\
\text { Kagayan, } \\
\text { Gayang, Lading } \\
\text { \& Pidah }\end{array}$ & 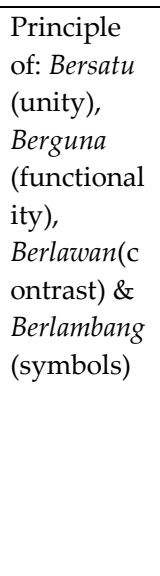 & $\begin{array}{l}\text { Refers to the sharp } \\
\text { eagle's talon that grips } \\
\text { the victims during } \\
\text { hunting. It delivers a } \\
\text { message about the } \\
\text { characteristics of the } \\
\text { Bajau community, } \\
\text { especially the men who } \\
\text { are trying to find } \\
\text { sustenance and dare to } \\
\text { face challenges. It also } \\
\text { reminds Bajau men to } \\
\text { always hone their skills, } \\
\text { talents, and ideas in } \\
\text { order to succeed. }\end{array}$ \\
\hline
\end{tabular}




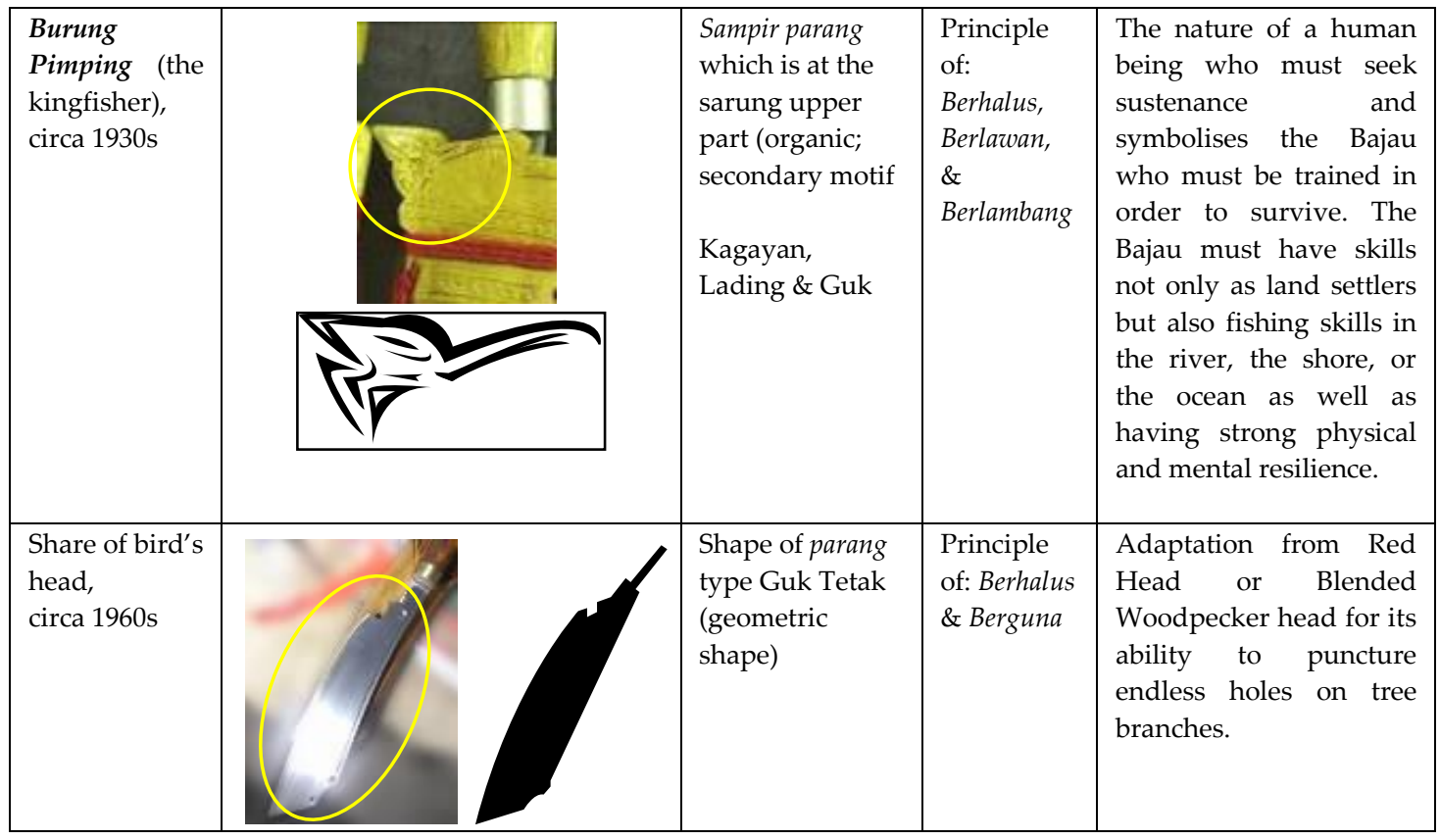

Table 2: Analysis of Manuk Motif Design

\begin{tabular}{|c|c|c|c|c|}
\hline Motif & $\begin{array}{l}\text { Pictures and illustrations of } \\
\text { the motif design }\end{array}$ & $\begin{array}{l}\text { Design form and } \\
\text { composition of } \\
\text { motif }\end{array}$ & $\begin{array}{l}\text { Principle of } \\
\text { Art and } \\
\text { crafts in } \\
\text { Malay } \\
\text { aesthetic }\end{array}$ & Philosophy \\
\hline $\begin{array}{l}\text { Tikuk Manuk } \\
\text { (roaster's } \\
\text { crest) } \\
\text { circa 1940s }\end{array}$ & & 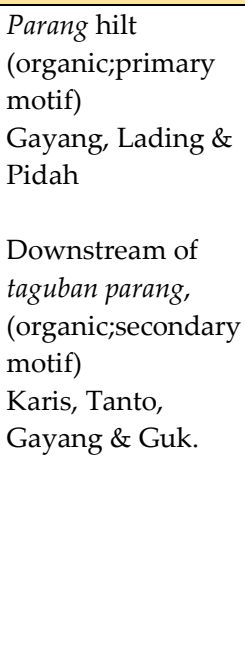 & $\begin{array}{l}\text { Principle of: } \\
\text { Berhalus } \\
\text { (indirect), } \\
\text { Berguna } \\
\text { (functional) } \\
\text { Bersatu } \\
\text { (unity), \& } \\
\text { Berlambang } \\
\text { (symbols) } \\
\\
\\
\text { Principle of: } \\
\text { Berhalus, } \\
\text { Bersatu, } \\
\text { Berlawan \& } \\
\text { Berlambang }\end{array}$ & $\begin{array}{l}\text { Adaptation from the } \\
\text { shape of the rooster's } \\
\text { head that expands } \\
\text { before a fight. Depicted } \\
\text { on the parang's hilt } \\
\text { because of its rapid } \\
\text { movement during the } \\
\text { action. This interprets } \\
\text { the characteristics of } \\
\text { Bajau men who are } \\
\text { firm, courageous, and } \\
\text { responsible to the } \\
\text { family. }\end{array}$ \\
\hline
\end{tabular}




\begin{tabular}{|c|c|c|c|c|}
\hline $\begin{array}{l}\text { Pere' Manuk } \\
\text { (roaster's } \\
\text { crest) } \\
\text { circa 1930s }\end{array}$ & & $\begin{array}{l}\text { Hilt \& parang's } \\
\text { sampir (organic; } \\
\text { primary motif) } \\
\text { (organic; } \\
\text { secondary motif) } \\
\text { Both motifs } \\
\text { applied to; Lading, } \\
\text { Kagayan \& } \\
\text { Gayang. }\end{array}$ & $\begin{array}{l}\text { Principle of: } \\
\text { Berhalus, \& } \\
\text { berlambang. }\end{array}$ & $\begin{array}{l}\text { Depiction from the } \\
\text { rooster's crest which is } \\
\text { also applied to the tanjak } \\
\text { or headband used by } \\
\text { Bajau men for } \\
\text { generations. The motif } \\
\text { symbolises the identity } \\
\text { and symbols of the } \\
\text { Bajau community, } \\
\text { especially the warriors } \\
\text { who are always calm in } \\
\text { facing difficult } \\
\text { situations but are still } \\
\text { able to protect } \\
\text { themselves from } \\
\text { physical and spiritual } \\
\text { threats. }\end{array}$ \\
\hline $\begin{array}{l}\text { Lawi Manuk } \\
\text { (roaster's tail) } \\
\text { circa 1930s }\end{array}$ & Source: Ismail Ibrahim (2009) & $\begin{array}{l}\text { Carved of parang's } \\
\text { blade (organic; } \\
\text { secondary motif) }\end{array}$ & $\begin{array}{l}\text { Principle of: } \\
\text { Berhalus, } \\
\text { Berlawan } \mathcal{E} \\
\text { Bermakna }\end{array}$ & $\begin{array}{l}\text { Lawi means roaster's tail } \\
\text { that has a curved and } \\
\text { attractive shape. } \\
\text { Usually carved on } \\
\text { parang's blade as a } \\
\text { reminder to always be } \\
\text { humble and respect the } \\
\text { elderly. }\end{array}$ \\
\hline $\begin{array}{l}\text { Lembayung } \\
\text { Manuk } \\
\text { (roaster's } \\
\text { spur), circa } \\
\text { 1970s }\end{array}$ & 1) & $\begin{array}{l}\text { Blade \& sarung } \\
\text { kerambit (organic } \\
\text { shape) }\end{array}$ & $\begin{array}{l}\text { Principle of: } \\
\text { Berguna } \mathcal{E} \\
\text { bermakna }\end{array}$ & $\begin{array}{l}\text { Adaptation from } \\
\text { rooster's spur. A small } \\
\text { sharp tip and mounted } \\
\text { on the leg of a rooster } \\
\text { for self-defence. } \\
\text { However, Bajau parang } \\
\text { makers applied it on the } \\
\text { blade and sarung with } \\
\text { additional elements of } \\
\text { Bajau identity. }\end{array}$ \\
\hline
\end{tabular}


Table 3: Analysis of Naga Motif Design

\begin{tabular}{|c|c|c|c|c|}
\hline Motif & $\begin{array}{c}\text { Pictures and illustrations of } \\
\text { the motif design }\end{array}$ & $\begin{array}{l}\text { Design form and } \\
\text { composition of } \\
\text { motif }\end{array}$ & $\begin{array}{c}\text { Principle of } \\
\text { Art and crafts } \\
\text { in Malay } \\
\text { aesthetic }\end{array}$ & Philosophy \\
\hline $\begin{array}{l}\text { Sarinaga, circa } \\
\text { 1990s }\end{array}$ & & $\begin{array}{lr}\text { Hilt and sampir } \\
\text { parang (organic; } \\
\text { primary motif); } \\
\text { Kagayan, Gayang } \\
\text { \& Guk. }\end{array}$ & $\begin{array}{l}\text { Principle of: } \\
\text { Berguna } \\
\text { (functional) } \mathcal{E} \\
\text { Berlambang } \\
\text { (Symbols) }\end{array}$ & $\begin{array}{l}\text { Adaptation from the } \\
\text { dragon's head shape. } \\
\text { Coat of strength and } \\
\text { dignity. } \\
\text { applied at Bually } \\
\text { sunduk (graveyard) } \\
\text { and } \\
\text { (traditional houses) }\end{array}$ \\
\hline $\begin{array}{l}\text { Sarinaga dan } \\
\text { sisik naga, } \\
\text { circa 1990s }\end{array}$ & 鏭 & $\begin{array}{l}\text { Sarung parang } \\
\text { (organic; } \\
\text { dominant motif); } \\
\text { Kagayan, Gayang } \\
\text { \& Guk. }\end{array}$ & $\begin{array}{lr}\text { Principle of: } \\
\text { Berhalus } \quad \mathcal{E} \\
\text { Berlambang. }\end{array}$ & $\begin{array}{l}\text { Refers to the shape of a } \\
\text { dragon and is depicted } \\
\text { in the form of } \\
\text { woodcarving in } \\
\text { emboss technique } \\
\text { (tebuk timbul). Then, } \\
\text { the taguban is } \\
\text { decorated with tipo } \\
\text { motif as secondary } \\
\text { motif. Symbolises } \\
\text { strength and power. }\end{array}$ \\
\hline $\begin{array}{l}\text { Sarinaga, circa } \\
2000 \mathrm{~s}\end{array}$ & & $\begin{array}{l}\text { Carved or } \\
\text { engraved on } \\
\text { parang's blade } \\
\text { (organic; } \\
\text { secondary motif) } \\
\text { Kagayan, Gayang } \\
\text { \& Guk. }\end{array}$ & $\begin{array}{l}\text { Principle of: } \\
\text { Berhalus, } \\
\text { Berlawan } \\
\text { Berlambang }\end{array}$ & $\begin{array}{l}\text { Observations through } \\
\text { artistic ceramics vase } \\
\text { China. Carving on the } \\
\text { surface of parang's } \\
\text { blade. Symbolise } \\
\text { power and firmness. }\end{array}$ \\
\hline
\end{tabular}

Analysis of the ukkil motif designs is based on interviews and documentation among the Bajau craftsmen at their parang's workshops, craft exhibitions and weapon collectors. The author then compiled and composed in a table with other columns to show the philosophies of Bajau Darat's ukkil motif design.

Five informants were selected to view the ukkil motif design that was compiled in the graphic table. The informants will determine whether they agreed with the interpretation and comments made by Tuan Arin B. Hj. Usop (79), the Bajau craftsman Adiguru in parang making. The informants were Tuan Bakah B. 
Jab (70, Kg. Siasai Tamu), Hj. Abdul Majad Halim (59, Kg. Siasai Jaya), Tuan Jamawid Soh (50, Kg. Siasai Jaya), Roslan Akah (50, Kg. Siasai Tamu), and Said Pawel (36, Kg. Siasai Jaya). The purpose of the interview is to take note each of their comments since the art of wood carving in parang Bajau depends on individual skill. However, it should be emphasised that there are some motifs created by the trainee or their apprentice during the learning process. Among the new motifs created by them are Sarinaga and Lembayung Manuk.

Through the SD analysis, the conducted interviews were clearer and more organised based on the opinions of the Bajau parang makers. The interpretation of the motif pattern is consistent and does not conflict with the philosophy of the Bajau Darat craftsmen in Kota Belud. Among the five informants, only two parang makers agree with the result of innovation and processing of Sarinaga motif and sisik naga (dragon scales) since it has less stylisation compared to the previous design of Bajau Laut's sunduk and lepa-lepa. Three informants are neutral and argue that the motifs should be stylised so that the actual characters are not clear or vivid.

All five informants strongly agree with the design of the blade and the sarung. They are satisfied with the craftsmanship invested in creating a good parang. This includes the excellent selection of wood, and the motifs were also carved in a very appropriate way. Meanwhile, other motifs such as the bird and manuk motifs received slight approval by the informants as the stylisation of its design maintains the identity of Bajau Sama carvings.

Table 4: Comments from Selected Gurukraf in Bajau Parang Making

\begin{tabular}{|c|c|c|c|c|}
\hline Scale 1 & Scale 2 & Scale 3 & Scale 4 & Scale 5 \\
\hline $\begin{array}{c}\text { Strongly } \\
\text { disagree }\end{array}$ & Disagree & Neutral & Agree & Strongly agree \\
\hline
\end{tabular}

\begin{tabular}{|c|c|c|c|c|c|}
\hline \multicolumn{5}{|c|}{ Tindukbelek E Motobelek } & Remarks \\
\hline \multicolumn{5}{|c|}{ Scale } & \multirow{2}{*}{$\begin{array}{l}\text { - Attractive, organic shape, diverse lines, firmness, courage, smart, neat } \\
\text { ability, intrinsic meaning, big, fierce, main motif, 3-dimensional, the } \\
\text { pride of heritage and identity. } \\
\text { - Five informants agreed with opinions and comments from Adiguru } \\
\text { Tn. Arin. }\end{array}$} \\
\hline 1 & 2 & 3 & 4 & 5 & \\
\hline \multicolumn{5}{|c|}{ Kekubelek } & Remarks \\
\hline \multicolumn{5}{|c|}{ Scale } & \multirow{2}{*}{$\begin{array}{l}\text { - Attractive, organic shape, fine lines, firmness, courage, intelligence, } \\
\text { neatness, ability, clear, intrinsic meaning, variation, secondary motif, } \\
\text { repetition, cutting of the skin. } \\
\text { - Five informants agreed with opinions and comments from Adiguru } \\
\text { Tn. Arin. }\end{array}$} \\
\hline 1 & 2 & 3 & 4 & 5 & \\
\hline
\end{tabular}




\begin{tabular}{|c|c|c|c|c|c|}
\hline \multicolumn{5}{|c|}{ Burung Pimping } & Remarks \\
\hline \multicolumn{5}{|c|}{ Scale } & \multirow[b]{2}{*}{$\begin{array}{l}\text {-Simple, organic and geometric shape, fine lines, harmony, skill, } \\
\text { endurance, neatness, abilities, intrinsic meanings, small, secondary } \\
\text { motives, heritage, identity and cultural values. } \\
\text { - Five informants agreed with opinions and comments from Adiguru } \\
\text { Tn. Arin. }\end{array}$} \\
\hline 1 & 2 & 3 & 4 & 5 & \\
\hline \multicolumn{5}{|c|}{ Tikuk Manuk } & Remarks \\
\hline \multicolumn{5}{|c|}{ Scale } & \multirow[b]{2}{*}{$\begin{array}{l}\text { - Interesting, organic, thick lines, repetition, rooster, firmness, courage, } \\
\text { speed, ability, courage, firmness, intrinsic meaning, multi- } \\
\text { dimensional, multi-dimensional, fierce, main motif, secondary motif, } \\
\text { responsible, heritage, identity and cultural value. } \\
\text { - Five informants agreed with opinions and comments from Adiguru } \\
\text { Tn. Arin. }\end{array}$} \\
\hline 1 & 2 & 3 & 4 & 5 & \\
\hline \multicolumn{5}{|c|}{ Pere' Manuk } & Remarks \\
\hline \multicolumn{5}{|c|}{ Scale } & \multirow{2}{*}{$\begin{array}{l}\text {-Organic shape, fine lines, calm, neat, proficient, intrinsic, simple, } \\
\text { dominant motives, pride, heroism, spirituality, identity spirit, identity, } \\
\text { legacy, Bajau philosophy and philosophy. } \\
\text { - Five informants agreed with opinions and comments from Adiguru } \\
\text { Tn. Arin. }\end{array}$} \\
\hline 1 & 2 & 3 & 4 & 5 & \\
\hline \multicolumn{5}{|c|}{ Lawi Manuk } & Remarks \\
\hline \multicolumn{5}{|c|}{ Scale } & \multirow{2}{*}{$\begin{array}{l}\text { - Attractive, organic shape, fine lines, assertions, curves, tidy, capable, } \\
\text { clear, intrinsic meanings, variations, repetitions, humility, secondary } \\
\text { motifs, legacies, developments, civilisations and symbols of identity. } \\
\text { - Five informants agreed with opinions and comments from Adiguru } \\
\text { Tn. Arin. }\end{array}$} \\
\hline 1 & 2 & 3 & 4 & 5 & \\
\hline \multicolumn{5}{|c|}{ Lembayung Manuk } & Remarks \\
\hline \multicolumn{5}{|c|}{ Scale } & \multirow{2}{*}{$\begin{array}{l}\text { - Clear, geometric shape, visualising, skilful, enduring, capable, varied, } \\
\text { new, progressive, functioning and different cultural identity with other } \\
\text { ethnicities in Sabah. } \\
\text { - Five informants agreed with opinions and comments from Adiguru } \\
\text { Tn. Arin. }\end{array}$} \\
\hline 1 & 2 & 3 & 4 & 5 & \\
\hline \multicolumn{5}{|c|}{ Sarinaga } & Remarks \\
\hline \multicolumn{5}{|c|}{ Scale } & \multirow[b]{2}{*}{$\begin{array}{l}\text { - Attractive, organic shape, multi-size, clear, multi-line, courage, } \\
\text { intelligence, intrinsic meaning, big, fierce, dominant and dominant } \\
\text { motifs, innovation, mythological influence, legend, 3-dimensional and } \\
\text { 2-dimensional, a symbol of greatness and firmness. } \\
\text { - Two informants strongly agreed, whereas three informants only agree } \\
\text { with the views and comments from Adiguru Tn. Arin. }\end{array}$} \\
\hline 1 & 2 & 3 & $\begin{array}{l}4 \\
(3)\end{array}$ & $\begin{array}{l}5 \\
(2)\end{array}$ & \\
\hline
\end{tabular}

The identity of a community's heritage pattern design plays an important role that distinguishes Bajau Darat (land settlers) with Bajau from other districts such as Tuaran, Kudat, Kota Marudu, or in the west coast of Sabah. This is pertinent to the message told by the previous Adiguru which emphasises on discipline and tradition. According to the informants, an engraving motif produced by a parang master should be agreed by other Bajau parang masters or craftsmen. The motif 
was then closely coordinated and developed by the second and third generation around the 1930s due to the factors of time and environment.

It is clear that the subject of a bird was a sort of heritage and was inherited from the Bajau Sama of Southern Philippines before their migration to North Borneo in 18 century. That is why there are similarities in the motif design in their basic motifs such as matilaak (circle), dapal (leaf), pako (fern), pialang (square), biagon (rectangle), katiambuang (diamond) or onsod (zigzag). Tuan Jamawid supports this matter due to the comprehensive Islamisation effects among the Bajau people of Kota Belud which specialise in parang hilt and taguban. Commercial factors among the Bajau parang makers have also encouraged economic growth while the design of motifs and the shape of parang are controlled firmly but subtly. However, he pointed out that some messages are still followed strictly by other Adiguru because they fear to be disobedient and be questioned by the embo-embo. Hence, the parang making techniques can only be taught amongst their families and selected individuals.

Generally, the number of fauna designs crafted by Bajau parang makers in Kota Belud is lesser than the flora and cosmic-based motifs. This is because the motifs of flora and cosmic are favoured by the craftsmen as the Bajau is mostly inherited and inspired to their observation and exposure to the environment. This is an evident gathered by the earlier generations who are involved with cultivation and agriculture, animal hunting, fishing, and traditional medications using herbs and plants. Even so, the previous generation of Bajau Sama design motif focuses on their graveyards, lepa-lepa and torogan.

\section{Conclusion}

Today, the production of parang Bajau is also similar to other handicraft products in the Malay world especially in Malaysia. The 6 principles of Malay aesthetic in art and craft by Zakaria Ali are also applied in their traditional weapons which help the researcher to analyse and understand the functions, purpose and even Bajau Darat's philosophy in parang making.

Although there are mystical elements such as the influence of gimbaran (saka) on some Bajau weapons, the parang maker community are able to curb and control it with divine values. It only involves a small number of practices and does not involve the whole Bajau Darat group in Kota Belud due to individual skills that make it different from one parang maker to another parang maker. The teaching of Islam since the previous generations as well as the desire to create more unique pattern of motifs for the purpose of commercial value have prevented them from worshiping the evil spirits by producing weapons with 
mystical elements. Other factors include educating and teaching the trainees to focus more on the quality and enhancement of parang, which includes the durability of the steel blades and the quality of the parang hilt and taguban.

The expression of the beauty of fauna via the bird subject gives a positive response to the value of appreciation and the philosophy of Bajau Darat craftsmanship. This study also relates to the history and development of motif pattern and design done by this community in Kota Belud. The source of inspiration to fauna elements is appreciated and depicted on the surface and shape of the Bajau parang. Although the art of parang making was influenced by the Tausugs, it seems like this traditional art of parang making became familiar with the Bajau Darat of Kota Belud.

\section{Acknowledgement}

Alhamdulillah, praise to Allah S.W.T, finally this article is written up for publication after few reviewing progress. I would like to thank my supervisors, and informants who spent their precious time to share their knowledge and experiences within the scope of the research topic. I would also like to express my gratitude to Dr. Hanafi Hussein, chief editor and BRJ editorial boards for such an opportunity and guidance in academic writings. There's so much to learn. I hope there will be another volume for me to contribute and participate in the future. Salaam A'laikum W.B.T.

\section{References}

Amilbangsa, L. F. (2006). Ukkil: Visual Arts of the Sulu Archipelago. Quezon City: Ateneo de Manila Press.

Amee Joan (2015). Seni Pembuatan Ilang Dan Nyabur: Kebanggaan Dan Simbol Masyarakat Iban di Sarawak. Unpublished manuscript. Retrieved from https://ir.unimas.my/id/eprint/8012/1/Seni_Pembuatan_Ilang.pdf

Asmiaty Amat, \& Lokman A. Samad. (2013). Bajau's Tekodon: A Preliminary Study. Journal of Educational and Social Research, 3(7), 445-459.

Baradas, D. B. (1968). Some Implication of the Okir Motif in Lanao and Sulu Art. Asian Studies: Journal of Critical Perspective on Asia, 6(2), 129-168.

Baszley Bee Basrah Bee, Md. Saffie A Rahim, Muhd. Shaukhi M. Radzi, \& Ismail Ali. (2015), Figura \& Fakta Perjuangan Islam di Sabah: Sharif Osman Dlm Konteks Sejarah Borneo: Suatu Penilaian Semula. Kota Kinabalu: ABIM Negeri Sabah.

Cojuangco, M. D. R. (2005). The Samals: In History and Legend. Manila: University of Santo Tomas.

Cuthbert, B. (1960). Islam in Sulu. Philippines Studies, 1(8), 51-57. 
Demetrio, F. R. (1974). Towards an Understanding of Philippine Myths. CETA Journal, 3(1).

Farish A. Noor, \& Khoo, E. (2003). Spirit of Wood: The Art of Malay Woodcarving. Hong Kong: Periplus.

Halina Sendera Mohd. Yakin. (2013). Cosmology and World-View among the Bajau: The Supernatural Beliefs and Cultural Evolution. Mediterranean Journal of Social Sciences, 4(9), 184-194.

Hurley, V. (1936). Swish of the Kris: The Story of the Moros. n.p.: E. P. Dutton \& Co, Inc. Retrieved from http://russbo.com/files/book/KRIS.pdf

Ismail Ali. (2010). Since Birth till Death, what is Their Status: A Case Study of the Sea Bajau in Pulau Mabul, Semporna. Journal of Arts Science \& Commerce, 1(1), 156-166.

Ismail Ibrahim. (2009). Warisan Motif dan Corak Etnik Sabah: Motif Ukiran Bajau: Satu Kupasan Awal Motif dan Bentuk Ukiran Sarung dan Hulu Guk Lading Kota Belud. Kota Kinabalu: Universiti Malaysia Sabah.

Ismail Ibrahim, Mohd Azareen Aminullah, Humin Jusilin, Mohd Pu'ad Bebit, Zaimie Sahibil. (2013). Warisan Seni \& Budaya: Masyarakat Kepulauan Pesisir Sabah. Kota Kinabalu: Univeristi Malaysia Sabah.

Jalil Borham, A. (2014, 18 March). Islam Di Nusantara. Paper presented at Kolokium Islam Pahang 'Meraikan Ilmu', Pahang State Museum, Tun Razak Theater, Sultan Abu Bakar Museum, Pekan, Pahang.

Khani, G. G., Ghasemi, P., \& Razmjooee, S. (2007). Immortals in Ancient Iranian Myths. Transoxiana, 12. Retrieved from http://www.transoxiana.org/12/ghasemi_khani-iranian_immortals.php

Lailawati Madlan, Chua Bee Seok, Jasmin Adela Mutang, Shamsul Amri Baharudin, \& Ho Cheah Joo. (2014). The Prejudice of Bajau: From Own and Others Ethnic Perspective: A Preliminary Study in Sabah. International Journal of Information and Education Technology, 4(3), 244-248.

Miller, J. M., Rizal, J. P., Cole, M. C., Santos, A. P., Miller, J. M., Jocano, F. L., \& Umali-Berthelsen, N. (2007). Philippine Mythology and Folklore. Filipino Martial Art Digest, Special Edition. Nevada: FMA Digest.

Mohd. Jirey Kumalah, Gusni Saat, Jabil Mapjabil, Rosazman Hussin, Teuku Afrizal, \& Mustapa Abu Talip. (2015). Kearifan Tempatan dan Potensinya sebagai Tarikan Pelancongan Berasaskan Komuniti: Kajian Kes Komuniti Bajau Ubian di Pulau Mantanani, Sabah. Geografia: Malaysian Journal of Society and Space, 11(12), 112-128.

Mohd Tajulhadis Ab. Halim. (2011). Penambahbaikan Reka Bentuk Seni Asli Parang Borneo Daro Aspek Semantik Kepada Reka Bentuk Komersil, tesis 
sarjana Seni Reka Perindustrian, Fakulti Seni Gunaan dan Kreatif, Universiti Malaysia Sarawak.

Mohd. Shaukhi, Bazley Bee, \& Ismail Ali. (2015). Figura \& Fakta Perjuangan Islam di Sabah: Perjuangan Datu Paduka Muhamad Salleh Datu Balu (Paduka Mat Salleh): Penelitian Dari Pandangan Islam. Kota Kinabalu: ABIM Negeri Sabah.

Nimmo, H. A. (1990). Boats of the Tawi-Tawi Bajau, Sulu Archipelago, Philippines. Asian Perspectives, 29(1), 51-88.

Noorajamsha Nasrin, \& Azizan H. Morshidi. (2015). Pembuatan Parang dan

Senjata Besi di Kota Belud Sabah: Satu Tinjauan. Retrieved from https://www.researchgate.net/publication/287865708

Nursuriani Shafee, \& Ismail Said. (2013). Types of Floral Motifs and Patterns of Malay Woodcarving in Kelantan and Terengganu. Procedia - Social and Behavioral Sciences, 105, 466-475.

Peralta, J. T. (1980). Southwestern of the Philippines Art. Manila: National Museum. Seyed Reza Ebrahimi, \& Elnaz Valaei Bakhshayesh. (2013). Manifestation of Evil in Persian Mythology from the Perspective of the Zoroastrian Religion. International Journal of English Language and Literature Studies, 2(1), 1-9.

Syamsul Azizul Marinsah, Mohammad Naqib Hamdan, Mohd. Farhan Md. Ariffin, \& Mohd. Anuar Ramli. (2016). Amalan Tradisi Masyarakat Bajau di Semporna Sabah: Kajian Menurut Hukum Islam. Jurnal Perspektif, 8(2), 135-149. Retrieved from https://www.researchgate.net/publication/311962757

Syamsul Azizul Marinsah, \& Mohd. Anuar Ramli. (2017). Sinkretisme Dalam Adat Masyarakat Bajau di Sabah. International Journal of Islamic Thought, 12, 8393.

King, V. T. (2013). Culture and Identity: Some Borneo Comparisons, working paper no.1, Institute of Asian Studies, Universities Brunei Darussalam.

Warren, J. F. (2003). The Balangingi Samal: The Global Economy, Maritime Raiding and Diasporic Identities in the Nineteenth-Century Philippines. Asian Ethnicity, 4(1), 7-29.

Waterson, R. (1989). Hornbill, Naga and Cock in Sa'dan and Toraja Woodcarving Motifs. Archipel, 38, 53- 73. Retrieved from http://www.persee.fr/doc/arch_00448613_1989_num_38_1_2589 


\section{List of Informants}

- Tuan Arin B. Usof (79), Bajau master craftsmen (parang weapon), Kg. Siasai Jaya, Kota Belud, Sabah.

- Tuan Hj. Ebin B. Adim (81), Bajau master craftsmen (parang weapon), Kg. Siasai Kumpang, Kota Belud, Sabah.

- Tuan Bakah B. Jab (70), Kg. Siasai Tamu, Kota Belud, Sabah

- Jamawid B. Soh (50), Adiguru Kraf Pandai Besi, Parang Bajau Kota Belud, HKK 19, Kompleks Kraf Jalan Conlay.

- Said Pawel (36), Kg. Siasai Jaya, Kota Belud \& HKK 19, Kompleks Kraf Jalan Conlay. - Hj. Majad Halim, Kg. Siasai Jaya, Kota Belud \& HKK 19, Kompleks Kraf Jalan Conlay.

- Roslan Akah (50), Kg. Siasai Tamu, Kota Belud, Sabah. 